\title{
Women in unity: re-imaging the female body in art
}

\author{
Laurel McKenzie
}

James Cook University

\begin{abstract}
A significant issue for feminist artists since the 1960s has been the disruption of the binary opposition associating maleness with the mind and culture, and femaleness with the body and nature. The binary has been contested by feminists in their efforts to subvert objectifying conventions and present empowering visual imagery of women, and the results at times have been vexed. This paper will consider some of these works as well as recent theorizing about embodiment, and efforts to separate "woman" from "nature" (to avoid essentialising limitations). Amelia Jones' (2006) theory of 'parafeminism', which aims to extend the achievements of earlier feminist artists in ways that provide strategies for dealing with contemporary regimes of power, will be used to structure the discussion.
\end{abstract}

\section{Introduction}

Tn this paper I look at some of the arguments and theoretical shifts which have occurred 1 around the imaging of women in artworks, and how they inform my visual practice. In particular, strategies proposed by Amelia Jones (2006) have relevance because they offer a way forward from the divisive debates around the issues of essentialism and anti-essentialism within feminism. Jones advocates what she calls 'Parafeminism' - para meaning both alongside and beyond, extending but not superseding earlier feminisms. She sees a progression for feminist artistic practice in ways which include a re-evaluation of past strategies for their effectiveness in empowering women, while at the same time avoiding tendencies to binary oppositions and universalisms within earlier feminisms.

Jones (2008) argues that the most significant bequest of feminism is 'a broader articulation of a politics of positionality across the field of the visual' which continues to revolve around the body, though not

... to be either positively or negatively rendered and performed, or critically dismantled, or shielded from a fetishizing gaze - but as a lived and living manifestation of the political effects of being variously positioned (identified) in today's global economies of information and imagery (Jones, 2008). 


\section{Image, representation and embodiment}

The terms "image" and "representation" occur frequently in discussions about visual art, the two terms often used as if they were equivalent. But there is an important difference in meaning. Hillary Robinson (2001 p. 440), claiming that the political significance of images can only be understood properly if the relationship between the two is explored, illustrates this point with the example of a painting of a nude woman in a landscape. The image here (Figure 1) is Giorgione's Sleeping Venus (however there are hundreds of candidates in the European painting tradition to choose from); a smooth-skinned, naked woman is sensuously arranged, outstretched and with eyes closed, in a verdant landscape. What the image represents is less definite -'particular understandings of femininity, luxury, passivity and beauty', perhaps (Robinson, 2001 p. 440). Questions arise around such things as why the naked woman is situated as she is in an otherwise-unpopulated landscape, and many other aspects of the painting. The linking of "woman" and "nature", through the metaphor of the body is, however, clear. And this linking has played a part in the economic, political and legal disempowerment of women through much of Western history.

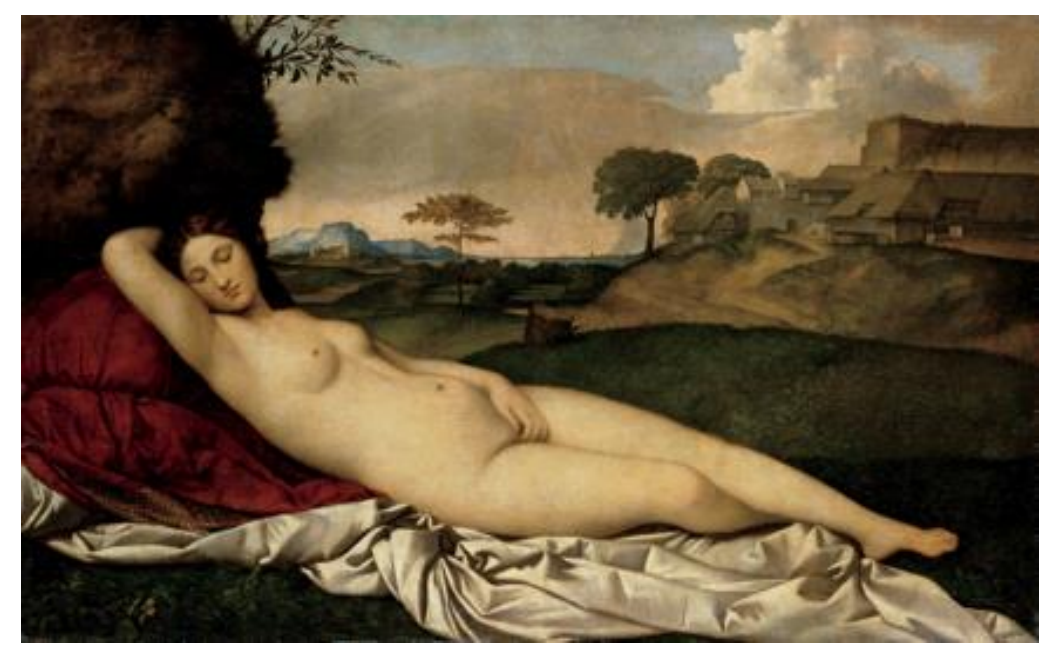

Figure 1. Giorgione and Titian, Sleeping Venus (also known as the Dresden Venus), 1510, oil on canvas, $108 \times 175 \mathrm{~cm}$

Both John Berger (1972 pp. 45-46) and Linda Nochlin (1988 pp. 136-144) alerted us to the many possible layers of meaning which attach to images of women, particularly naked women, and to how different our response might be if a man was to replace the woman in such imagery (Figure 2). What might such images represent? Meanings in visual artworks are demonstrated to be neither universal nor fixed - that is, they are 'culturally and historically specific ... with no fixed "truth" that can be uncovered' (Chadwick, 1990 p. 358). 

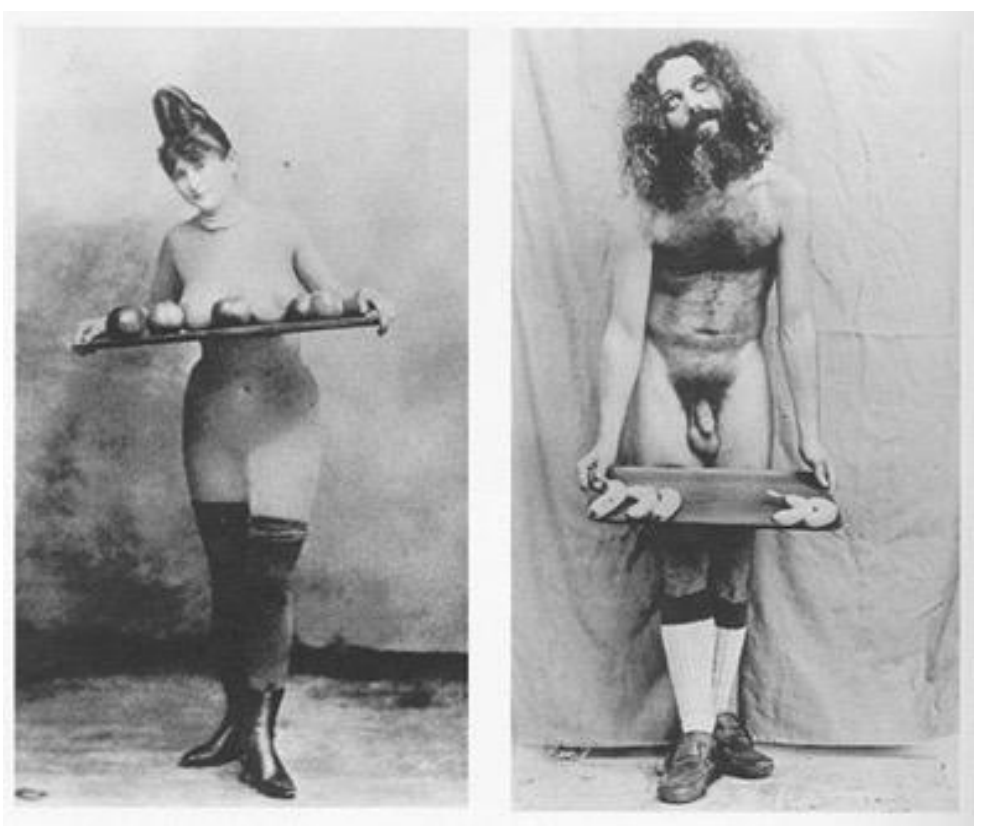

Figure 2. left, Achetez des pommes, from a late nineteenth century French magazine; right, Linda Nochlin, Achetez des bananes, 1972, photograph

From the late 1960s and early 1970s, Second Wave feminists began to challenge some of the conceptual frameworks and social constructs underlying artistic practice, including the binary oppositions that linked femaleness with nature and the body, and maleness with culture and the mind. The assumption behind these oppositions - that 'Women are somehow more biological, more corporeal, and more natural than men' (Grosz, 1994 p. 14) was significant because it appeared to make rationality unachievable (Lennon, 2010). Furthermore, oppression and limitations imposed on women's social and economic roles could be justified on biological terms, their bodies being presumed to be weaker and more susceptible to change (Grosz, 1994 p. 14).

Second Wave feminist artists employed a range of strategies - activist, often collaborative, and sometimes highly personal - to undermine limiting perceptions. They adopted a generally celebratory approach to imaging women's bodies and representing their experiences, seeking to reclaim the female body from what Amelia Jones (in Broude. \& Garrard., 2005) describes as 'its patriarchal construction as passive object, fetishized through structures of male desire' (Jones in Broude. \& Garrard., 2005 p. 417).

From the 1970s, an ideological shift occurred against the work of artists like Judy Chicago (Figure 3), Miriam Shapiro (Figure 4), and Nancy Spero (Figure 5). However, in the subsequent decades, as I will show, some re-evaluation of these artists has taken place. Several large-scale survey exhibitions of work by women artists, accompanied by substantial publications, have presented the opportunity to reassess a volume of feminist works from a contemporary perspective. There has also been a resurgence of some areas of practice in the 21 st century which draw on the work of earlier feminist artists and their investigation of 
power, social relationships and artistic agency. These factors, in unison, contribute to a reinvigoration of feminist concerns in contemporary practice (Millner, 2015). Before considering current practice more closely, I will outline the terms of the essentialism/antiessentialism debate.

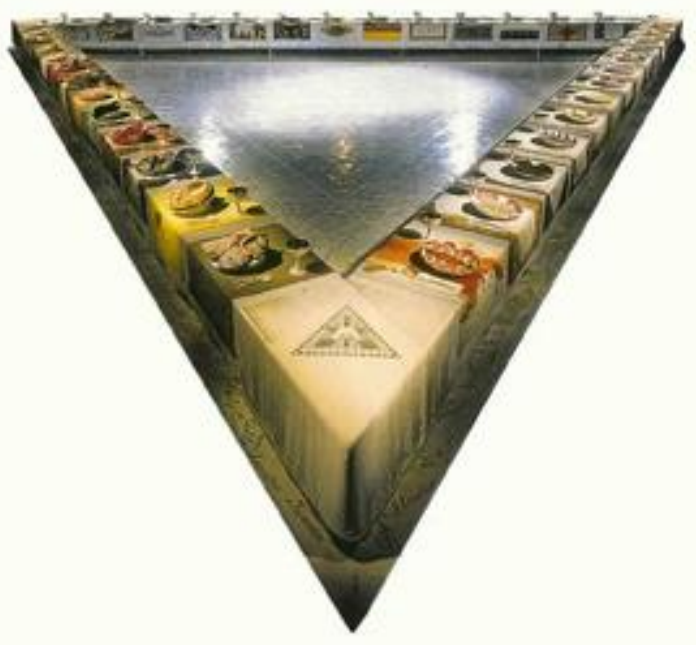

Figure 3. Judy Chicago, The Dinner Party, 1974-1979, wood, ceramic, fabric, needlework, metal, paint

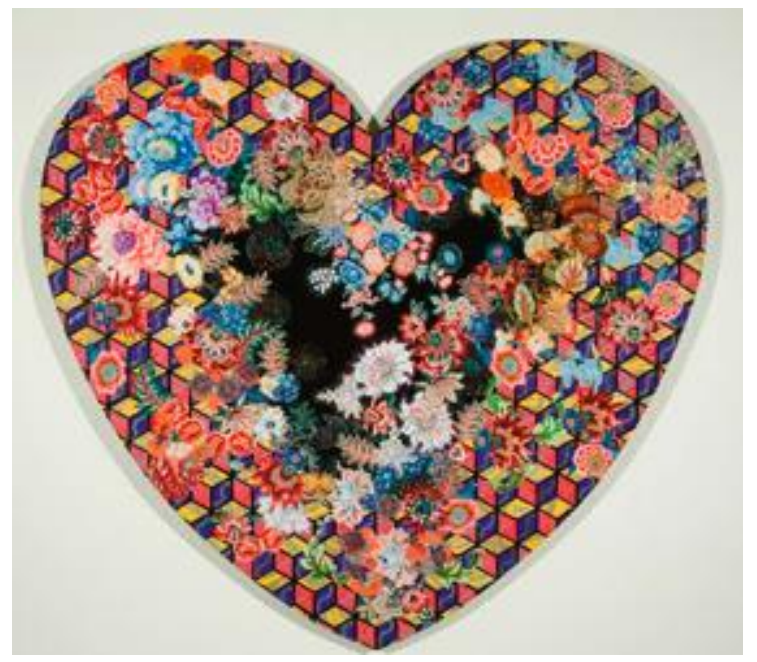

Figure 4. Miriam Schapiro, Heartland, 1985, acrylic and fabric collage on canvas, 216 x $239 \mathrm{~cm}$ 


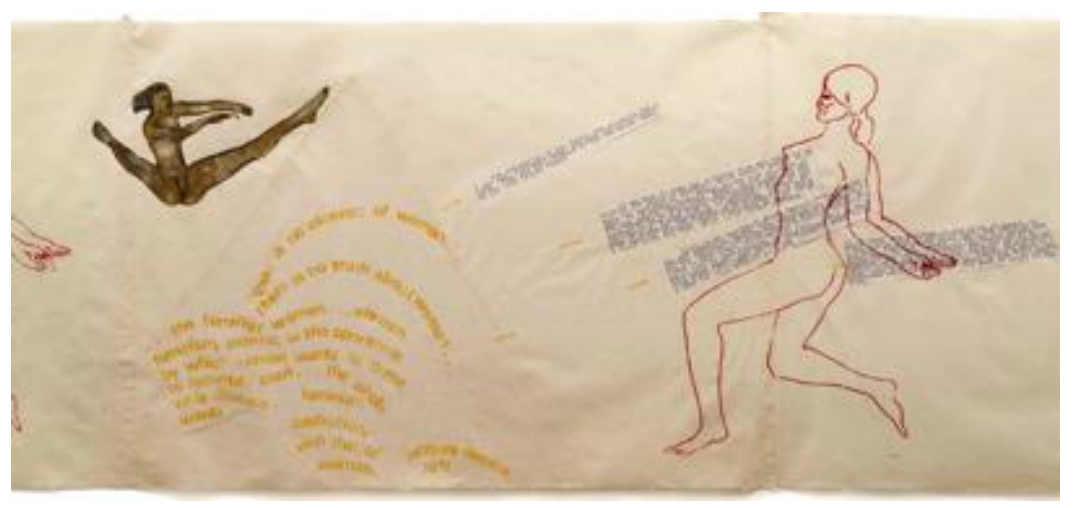

Figure 5. Nancy Spero, Notes in time: triple canopy (detail from 24 numbered panels), 1979, handmade paper, collage, painted and printed components, $\mathrm{H} 50 \mathrm{~cm}$

\section{Anti-essentialism and its consequences for imaging}

Elizabeth Grosz (1994) defines the concept of essentialism, within feminism, as referring to 'the attribution of a fixed essence to women ... assumed to be given and universal and ... usually ... identified with women's biology and "natural" characteristics' (Grosz in N. Schor $\&$ Weed, 1994 p. 84). Sometimes this essence might lie outside nature or biology, and involve psychological qualities ('nurturance, empathy, supportiveness' for example) or be apparent in social practices (such as 'intuitiveness, emotional responses') (Grosz in N. Schor \& Weed, 1994 p. 84). Ellen Rooney stressed that the body is the central issue - 'The body is of course essentialism's great text ...' (Rooney in N. Schor \& Weed, 1994 p. 152).

"Essentialism" became one of the most frequently used terms in assessing feminist-oriented theories concerning 'the nature of women (and men)' - along with "biologism", "naturalism" and "universalism" (Grosz in N. Schor \& Weed, 1994 pp. 84-85). The latter descriptions are sometimes used synonymously with "essentialism", though there are subtle differences in meaning. Each, however, deals with 'fixity and limits definitionally imposed on women' (Grosz in N. Schor \& Weed, 1994 p. 82). Such assumptions about fixed characteristics, shared by all women, are rejected by anti-essentialists because they have been used to rationalise limitations imposed on women. Furthermore, such assumptions preclude possibilities for change.

Crucially, essentialism is generally defined in opposition to difference. Anti-essentialists, rejecting the notion that women can be conceptualised as a unified group with innate characteristics, argued instead for recognition of the specific historical, geographical and social situations of women, and for a cultural basis for the construction of identity:

The doctrine of essence is viewed as precisely that which seeks to deny or to annul the very radicality of difference. The opposition ... reminds us that a complex system of cultural, social, psychical, and historical differences, and not a set of pre-existent human essences, position and constitute the subject (Fuss, 1989 p. xii). 
Divisive debates around essentialism and anti-essentialism continued in the 1990s, with the label of "essentialism", according to Schor (1995), 'invested with 'the power to reduce to silence, to excommunicate, to consign to oblivion' (N Schor, 1995 p. 47). There were, however, many strands to the debate, and significant differences within essentialism, or rather, multiple essentialisms.

The theoretical debates continued and were expanded in subsequent feminist theorising. My specific interest, however, is in the visual arts context where the essentialist/ anti-essentialist rift, as related by Mira Schor, was exposed during a debate held in 1987 at the New Museum of Contemporary Art (New York): The Great Goddess Debate - Spirituality vs. Social Practice in Recent Feminist Art (Schor in Broude. \& Garrard., 1994 p. 254). This pivotal debate coincided with a posthumous retrospective exhibition of the work of Ana Mendieta in the same museum (Wykes \& Gunter, 2005).

The coincidence of the two events was significant because Mendieta placed her body (or traces of it) in natural environments in works such as her Silueta series (Figures 6 and 7), apparently aligning women and nature. This juxtaposition led to her work being categorised as "essentialising" (Best, 2007 pp. 57-61). There was a sense also of allusion to an imaginary, matriarchal past (linked to the Great Goddess in the title of the debate mentioned above), with the supposition of a pre-patriarchal condition. This supposition carried the implied understanding that because patriarchy had an origin in time, it could also have an end (Butler, 1990 p. 48).

Later reassessments of Mendieta's work highlight the problem of such categorisations. Some theorists re-read Mendieta's repetition of performance of the woman/nature alignment in terms of a postmodern sensibility and an attempt at the 'destabilization, deconstruction or subversion of identity' (Best, 2007 p. 64). This revisionist approach locates her work strategically between 'essence and inessence' (Blocker, 1999 p. 49). 


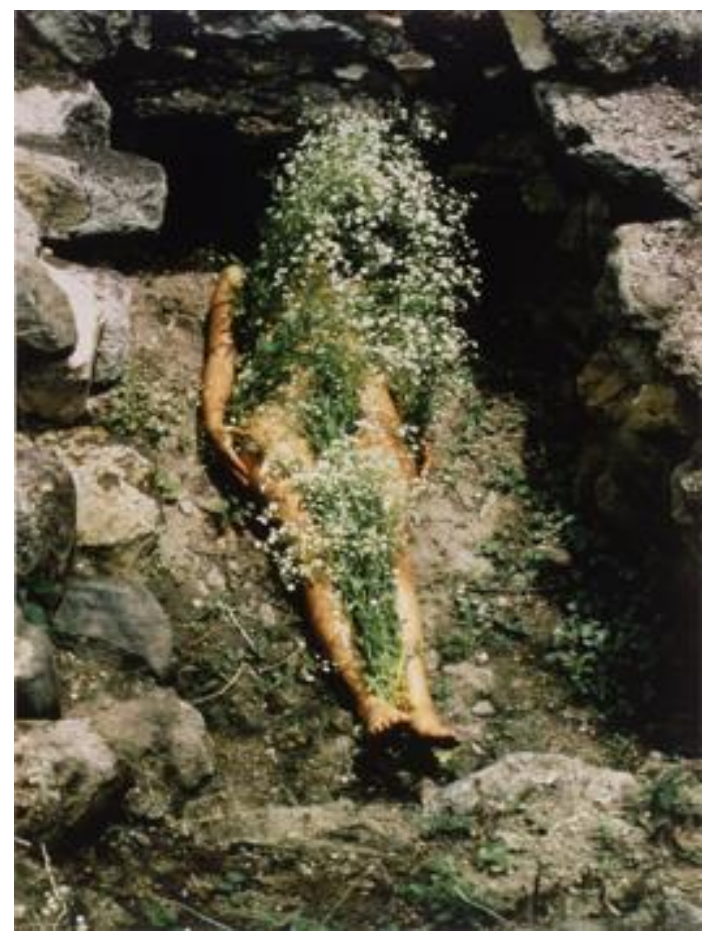

Figure 6. Ana Mendieta, from Silueta series, 1973 - 1980, C-type photographic prints

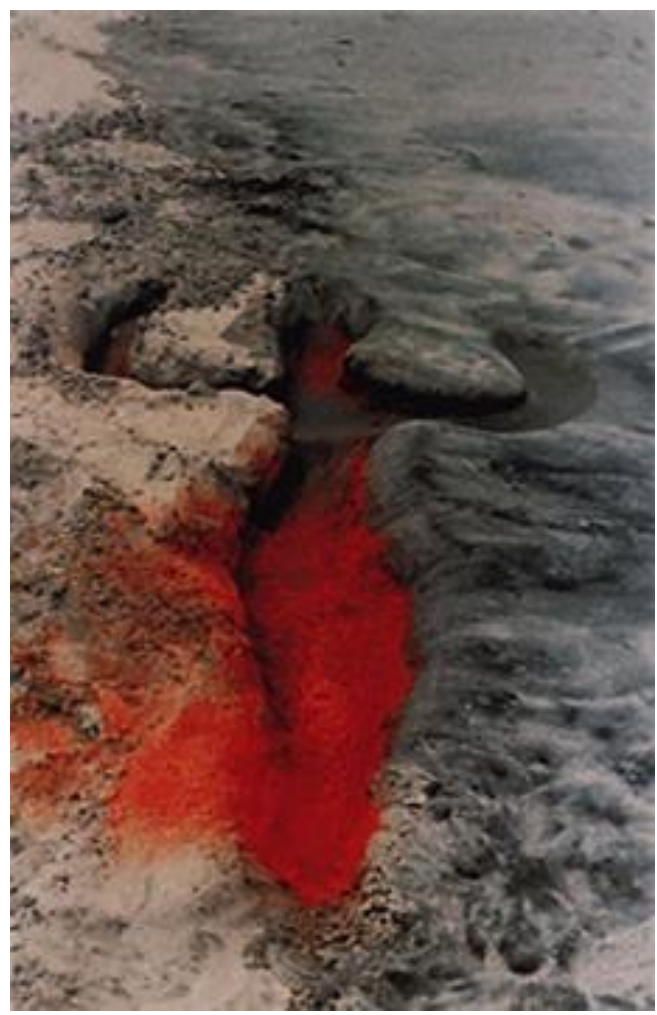

Figure 7. Ana Mendieta, from Silueta series, 1973 - 1980, C-type photographic prints 
Judy Chicago's vast, collaborative work, The Dinner Party, which aims to reclaim historical women from obscurity, was first exhibited in 1979. It was condemned for its essentialism, based, in part, on what critics saw as an implied universalising category of "woman", a female lineage with biological difference as its basis. The work was also seen to reduce women to vaginas and wombs - or what Chicago and others referred to as "central core" imagery (Chadwick, 1990 p. 358) (Figure 8); the work includes thirty-nine large dinner plates, shaped in stylised images of vulvas, at place settings for particular women. As psychoanalysis became an important methodology for the interpretation of artworks in the 1980s, the depiction of separated parts of the anatomy came to be seen as fetishising (Reckitt, 2012). Chicago argued in her defence that the central core imagery was part of a strategy to 'reverse the devaluation of female anatomy in patriarchal culture' (Chicago cited in Chadwick, 1990 pp. 358-359).

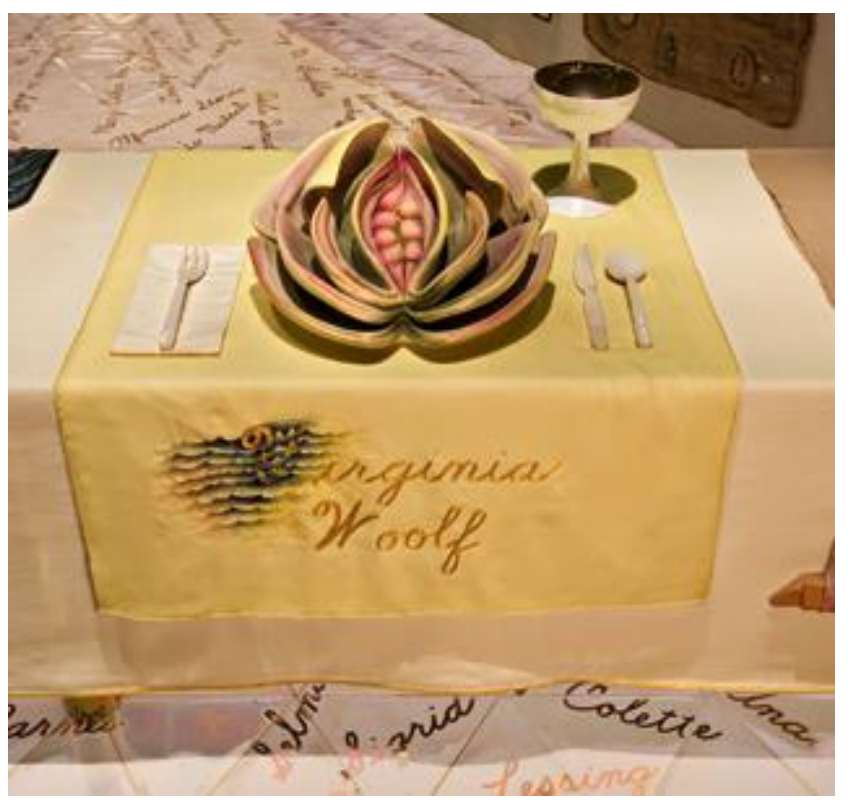

Figure 8. Judy Chicago, The Dinner Party, detail (Virginia Woolf place setting), 1974-79, mixed media: ceramic, porcelain, textile

Revisiting the arguments in the 1990s, some feminist historians, theorists and critics concluded that women artists who, like Chicago, were accused of essentialism, were more strategic and less simplistic than their detractors gave them credit for (Reckitt, 2012 p. 12). The artist were, it could be argued retrospectively, undertaking a necessary reclamation of female forms for political ends; it was a step in the process of creating a self-affirming art that was 'for women rather than about them' (Jones, 2003 p. 9). These strategies were needed, asserts Jones (2003), to denote gender as informative of cultural practice and to deny the "masculinist notion of "universality" that guaranteed the privileging of male-invented forms and themes as neutrally aesthetic' (Jones, 2003 p. 9).

Another strategy adopted by Miriam Schapiro and other artists was the use of textiles - actual fabrics and textile patterning traditions - in their work, as a response to the disparaging label 
of "decorative" which had been used in relation to "women's work" and craft practices.

Schapiro's works, although abstract, functioned in opposition to what was perceived to be the gendered and exclusionary practices of Modernist geometric abstraction. Fabrics, collage and assemblage were combined with acrylic paint in works which were described (by the artists themselves) as "femmage" (Chadwick, 1990 p. 364).

In Anatomy of a kimono, Schapiro (Figure 9) used scale (over 15 metres in length) to 'reinvest what has previously been dismissed as modest with the scope of history painting' (Schapiro quoted in Chadwick, 1990 p. 364). She sought to 'redress the trivialisation of women's experience' (Schapiro quoted in Broude. \& Garrard., 1994 p. 25). Artist and critic Harmony Hammond (1977) observed that writing on feminist art at the time failed to identify the political potential of abstract work by feminist artists, referring to the illusory separation of art and politics which prevailed in formalist, Modernist critiques.

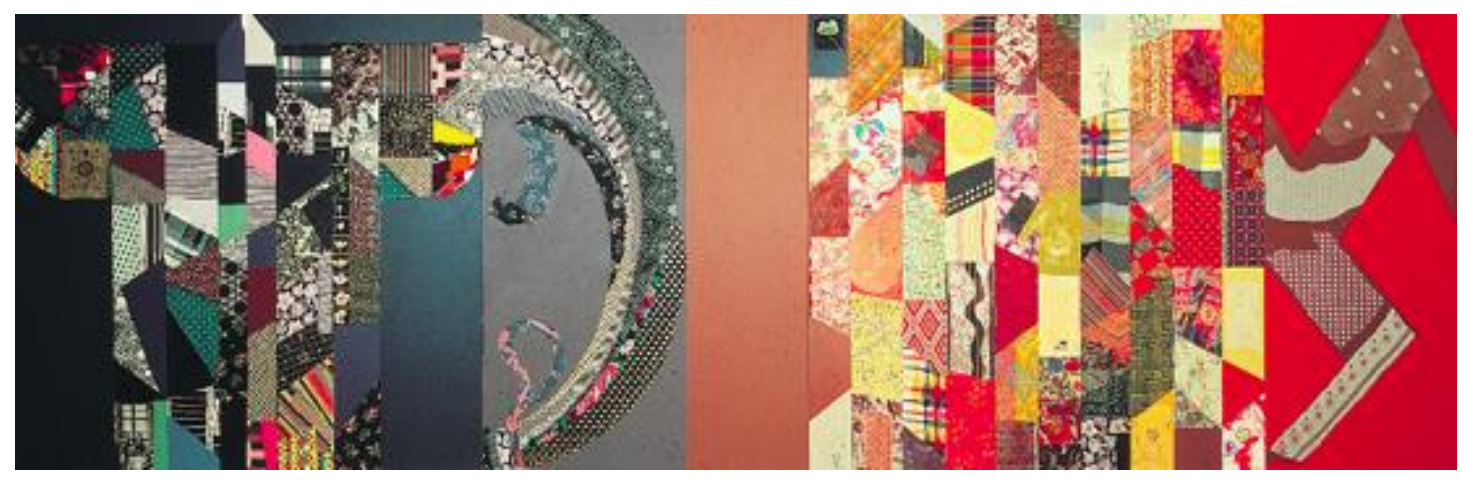

Figure 9. Miriam Schapiro, Anatomy of a kimono, detail, 1976, fabric and acrylic on canvas, total size $2 \times 17.4$ metres

Anti-essentialist critics saw the use of historically "female" art forms as reinforcing gendered stereotypes (Broude. \& Garrard., 1994 p. 25). However, viewed from another perspective, the works can be seen to challenge biological essentialism because they were re-valuing an area of visual expression that had long been gendered as feminine.

Nancy Spero also worked with less conventional materials, with political intent. She used paper and collage with printed imagery and text in large-scale, multi-panel works. In Codex Artaud (Figure 10), for example, Spero engaged with language, its limitations and conventions, quoting from French writer Antonin Artaud. She drew also on the writings of Hélène Cixous (1975) and her proposal for writing of the female body and female difference in language and text;

... fragmented images, fragments of words, tongues that swell into the phallus of the Symbolic Order which governs language in patriarchy, are all used to reinforce the marginality of Artaud's, and by extension woman's, language (Chadwick, 1990 p. 359). 
Spero recast women rom historical contexts of subordination into active, empowered characters, demonstrating physical strength and mythic power (Chadwick, 1990 p. 360), characteristics which could be seen as essentializing. She also uses repetition and irony to explore issues including the shifting identities of women. Her work can be seen, from a current perspective, as representing an investigation into how sex-roles are circumscribed; she is credited with at once exposing such roles and challenging their inherent contradictions (Dobie in Zeglin Brand \& Korsmeyer, 1995 p. 224).

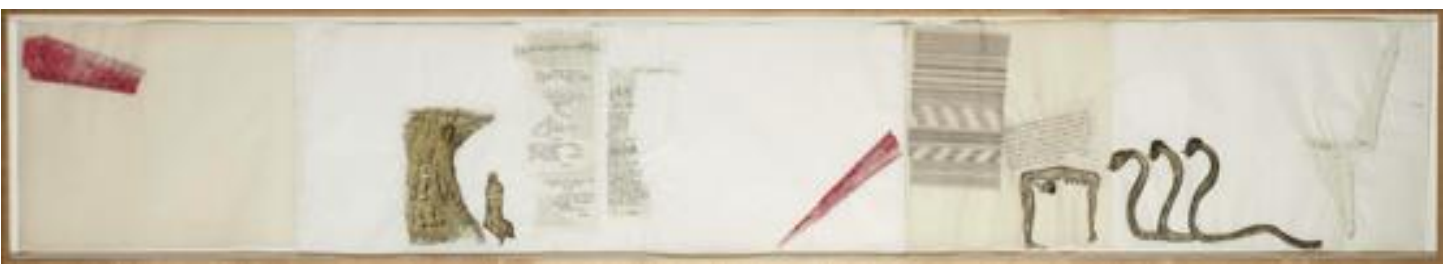

Figure 10. Nancy Spero Codex Artaud vii (detail from total of 34 scrolls), 1972, typescript, gouache, collage on printed paper

The above-mentioned artists and others who worked performatively with their bodies, or who represented women's bodies directly in their works, became marginalised in critical dialogue, though many of their works had been successful in drawing a connection between biological and social understandings of the body (Marsh, 1993 p. 171). The move in feminist art of the late 1970s and 1980s was towards a deconstruction of 'the pleasure that men in patriarchal culture take in representations of the female body', and this somewhat displaced the focus of the essentialism debate. The following artists are some of those who responded to this shifting theoretical focus.

Mary Kelly eliminated figurative depictions of the body in order to eliminate it as spectacle. She articulated women's experiences and desires through mixed media, multi-component works such as Post-Partum Document (1973-79) (Figures 11 and 12). Documentation and the assemblage of artefacts record the relationship between herself and her young son, and the child's acquisition of language. The work incorporates the influence of psychoanalytic theory of sexual difference, drawing on Lacan's investigation of language and sexuality (Chadwick, 1990 pp. 403-404). 


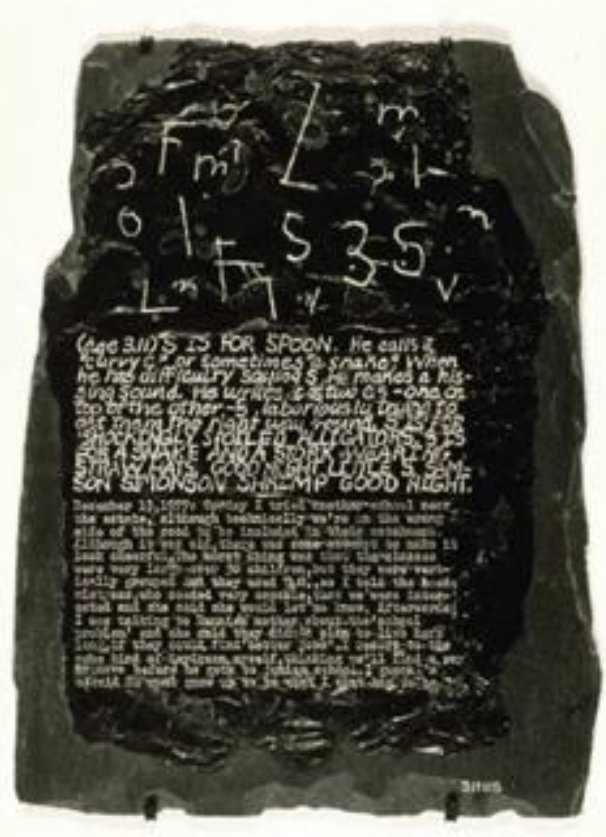

Figure 11. Mary Kelly Post-Partum Document detail from Documentation VI: Pre-Writing Alphabet, Exergue and Diary, 1973-79, part of a 165-part work including slate and resin units and diagrams
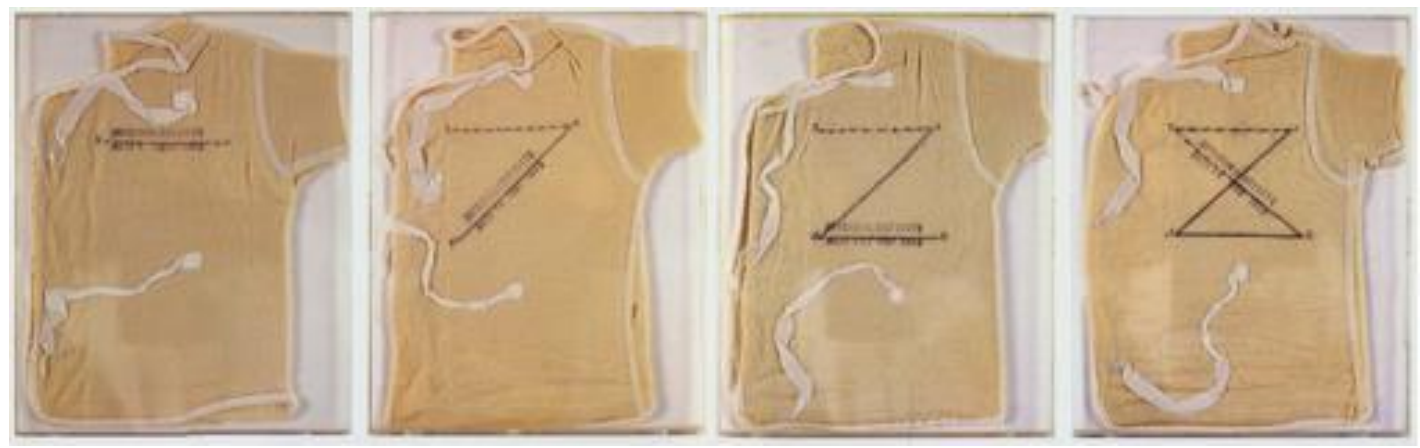

Figure 12. Mary Kelly Post-Partum Document, detail from Introduction, 1973-79, Perspex units, white card, wool vests, pencil, ink

For Jenny Holzer, text became a principle visual element. She distilled the contents of literature and philosophy texts into simple, one-sentence statements for her Truisms series (Plate 13). These lines, which read like slogans, were printed in alphabetical order on sheets of paper which were pasted on buildings in New York. Members of the public interacted with the works, adding, deleting, scribbling and commenting on the statements, making the project in one sense a participatory one, aligned with community activism. 


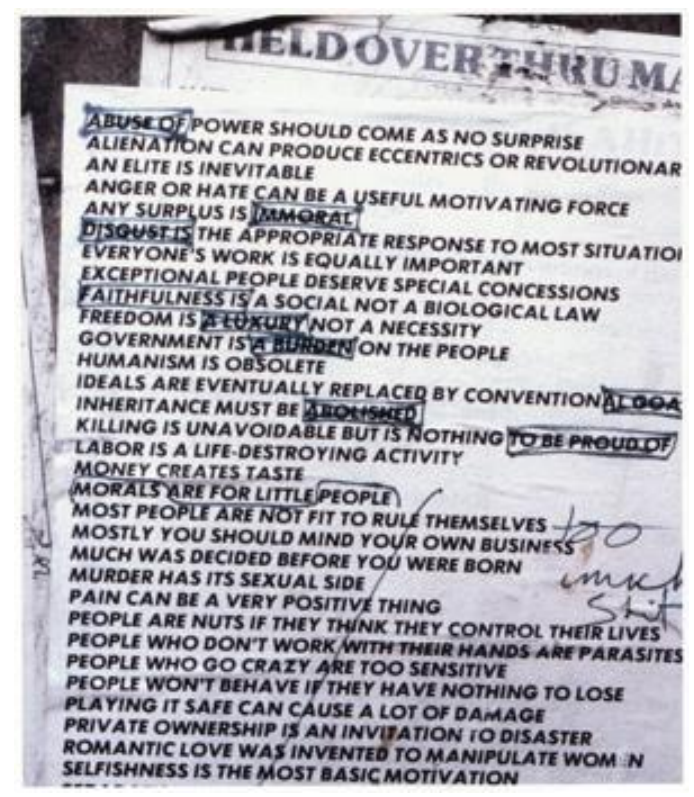

Figure 13. Jenny Holzer Selections from Truisms 1982, offset ink on paper, each sheet $91.5 \mathrm{x}$ $61 \mathrm{~cm}$

Amongst the artists who were early in employing deconstructive strategies - questioning the construction of identity and power in visual culture by quoting, exposing and fragmenting the semiotic devices at work - is Martha Rosler. Her Semiotics of the Kitchen (1975) (Figure 14), for example, employed critical theory with humour, thinly masking fury (White, 2011).

Standing in a kitchen, as in a television cookery demonstration, Rosler brandishes utensils as she recites the alphabet, illustrating each letter with a domestic item. The visual and verbal languages of popular culture, including television and advertising, are manipulated to make their workings apparent (Buchloh cited in Owens, 1994 p. 181).

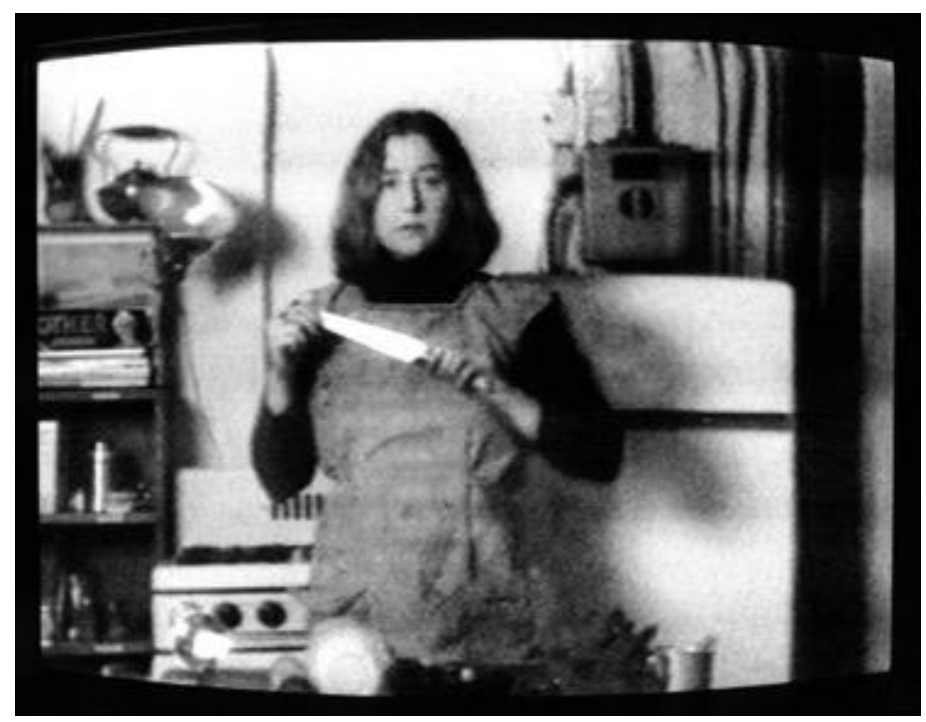

Figure 14. Martha Rosler, Semiotics of the kitchen, 1975, still from video, black and white, sound, 6 minutes 
Cindy Sherman confronts the viewer with the difference between the real and the representational in photographs of her altered, self-image. She contrives 'masquerades of femininity' (Reckitt, 2012 p. 40) in her Untitled (Film Still) series (1977-1980) (Figure 15) and History Portraits (1989-1990) (Figure 16). The images mimic character archetypes and recognisable styles or genres, though they never exactly reconstruct any given original. This links Sherman's work to Butler's (2007) proclamation that '... gender is a kind of imitation for which there is no original' (Butler quoted in Reilly \& Nochlin, 2007 p. 42). Impersonation here functions as parody, exposing the artifice of the construction of stereotypes by the mass media.

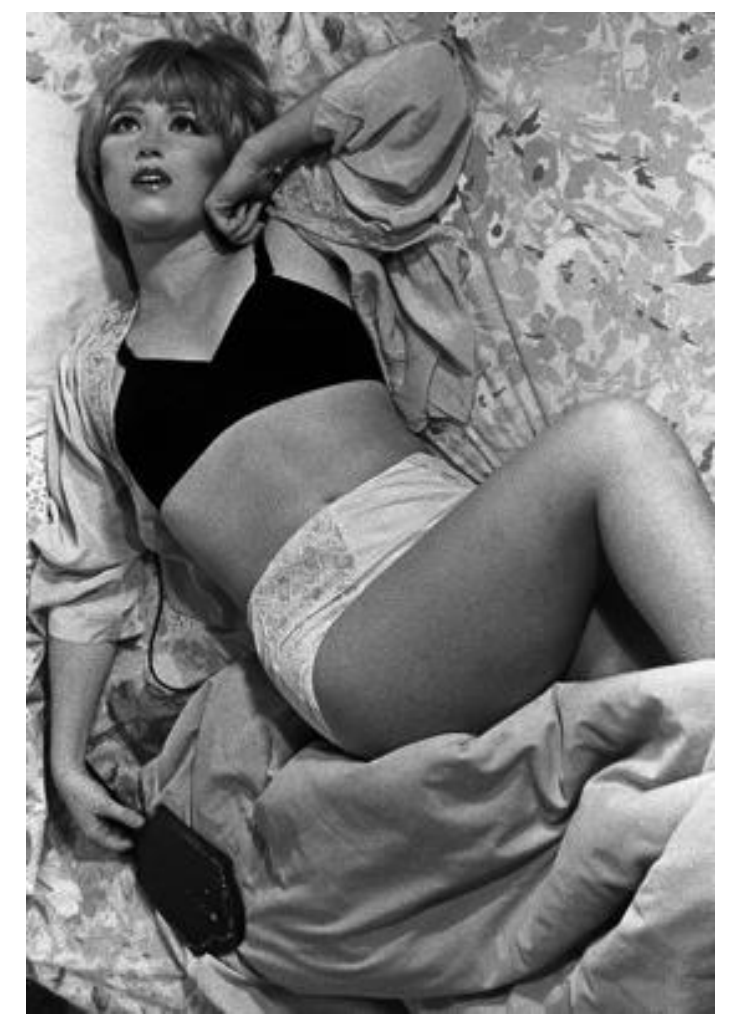

Figure 15. Cindy Sherman Untitled Film Still \# 6, 1978, Gelatin silver print, 23 x $16.5 \mathrm{~cm}$ 


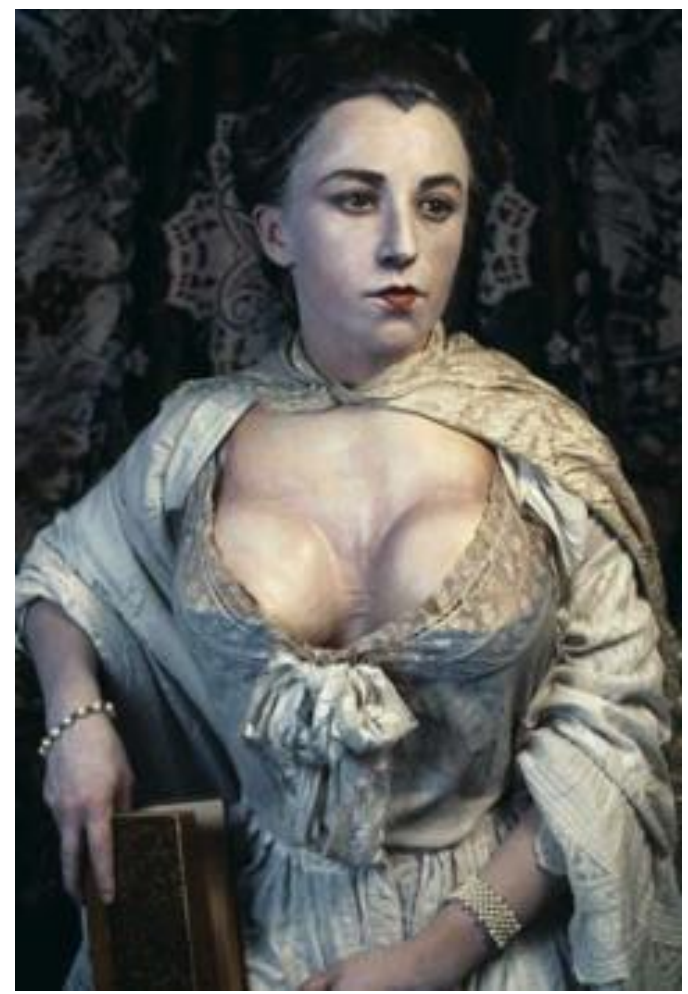

Figure 16. Cindy Sherman, Untitled \#183-A (History Portrait series), 1988, Colour photograph, $124.5 \times 88.9 \mathrm{~cm}$

\section{Re-representation}

The works of the artists discussed above can be seen as critiques of representation, 'about representation, mediated by culture' (Schor in Broude. \& Garrard., 1994 p. 255). They have tended to be discussed in the context of postmodernism rather than feminism, but the artist's conceptual frameworks and working practices can be seen to have emerged from earlier, activist feminist art. Their strategies and aesthetic concerns are more closely linked to those of their feminist predecessors than those of the male contemporaries with whom they are often grouped. They engaged with issues around sexuality and representation as part of a political project.

My practice engages with some of the strategies outlined. In particular, I use seriality, where multiples or series of images function as part of a whole, and appropriative strategies, where the original meaning of the appropriated works is altered in the process of reiteration. Though not uniquely feminist, these visual strategies are prevalent in feminist practice. Both are incorporated in the installation work, Wall of watery women: versions of Venus (Figures 17, $18,19)$ which is made up of multiple, fragmented components - quotations of historical versions of the birth of Venus, a naked woman in and as nature. 


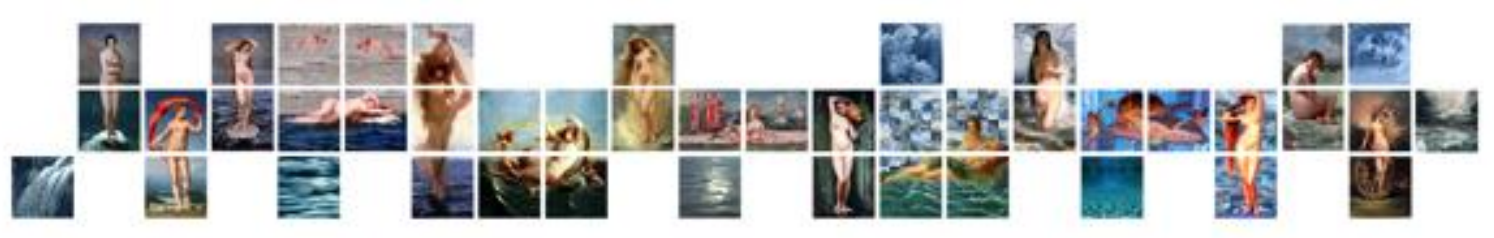

Figure 17. Laurel McKenzie The birth of Venus: wall of watery women, 2014-2015, archival pigment print on canvas, $8.28 \mathrm{~m} \mathrm{x} 98 \mathrm{~cm}$
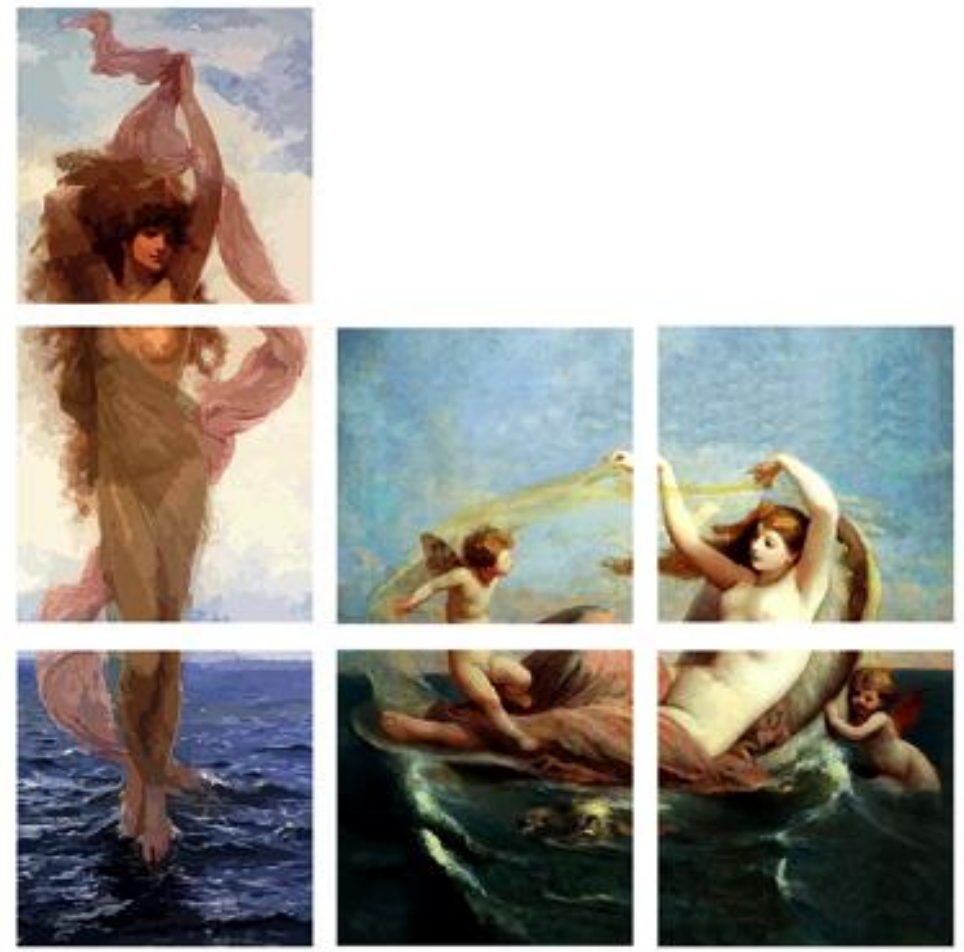

Figure 18. Laurel McKenzie The birth of Venus: wall of watery women (detail), 2014-2015, archival pigment print on canvas 

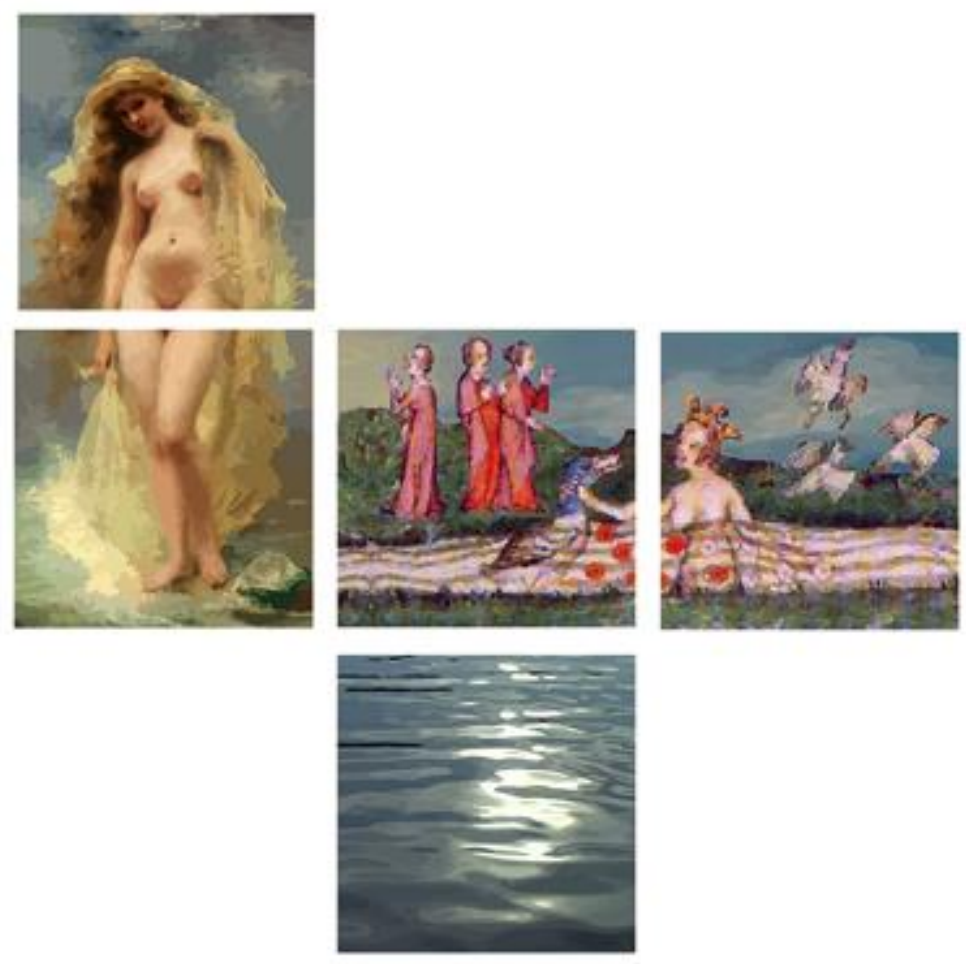

Figure 19. Laurel McKenzie The birth of Venus: wall of watery women (detail), 2014-2015, archival pigment print on canvas

Victor Burgin (2001) observed that there are, 'a myriad of ... delegates from a history of Western representations flooded with watery images of women - from the Birth of Venus to the Death of Ophelia' (Burgin quoted in Robinson, 2001 p. 448). This observation fostered my interest in how women have long been linked with nature - and the element of water in particular, with its cosmogenic connections with fertility and fecundity - and how that disempowering connection can be exposed.

The Wall of watery women: Versions of Venus consists of forty-four small $(30$ x $30 \mathrm{~cm}$ square) panels, reiterating Venuses from over two millennia of imaging, fragmented into two, three or four panels, with the watery origins of the subject amplified. In Greek mythology, Aphrodite/Venus (goddess of love and beauty) is born out of sea foam. Cronus, the son of sky-god Ouranos, castrated his father and threw the severed genitals into the sea, which began to foam. From the churning sea, Venus emerged, fully formed, as a virginal young woman of unsurpassed beauty. She became, as a subject, a vehicle for the projection of ideals of female beauty, representing the embodiment of the generative powers of nature.

Venus here is presented in a broken grid, the components reading both vertically and horizontally, suggesting a kind of continuum. But there is no linear chronology. This work sets out to undermine the commodification of idealised female bodies, and their connection with nature, by underlining it. 
My visual practice proceeds from Jones' conviction that a renewed interest in the achievements of earlier feminisms, and an extension of the impulses of those artists, can provide strategies which can be adapted to deal with contemporary regimes of power. Jones stresses that the transition from modernism to a contemporary global economy is 'characterized by the degree to which we have internalized our own objectification ...' (Jones, 2008 p. 11). This internalisation of 'being seen' has different implications for different people, according to their distance from power. The body is not rejected as a subject around which feminist practice can be based. Exaggerating the binary opposition of female/nature/body versus male/culture/the mind is a strategy for disrupting its logic. 


\section{Works Cited}

Berger, J. (1972). Ways of seeing. London: BBC \& Penguin Books.

Best, S. (2007). The serial spaces of Ana Mendieta. Art History, 30(1), 57-82.

Blocker, J. (1999). Where is Ana Mendieta?: identity, performativity, and exile. Durham: Duke University Press.

Broude., \& Garrard. (Eds.). (1994). The power of feminist art: emergence, impact and triumph of the American feminist art movement. New York: Abrams.

Broude., \& Garrard. (Eds.). (2005). Reclaiming female agency: feminist art history after postmodernism. Berkeley: University of California Press.

Butler, J. (1990). Gender trouble: feminism and the subversion of identity (2nd ed.). New York: Routledge.

Chadwick, W. (1990). Women, art and society (3rd ed.). London: Thames \& Hudson.

Cixous, H. (1975). The laugh of the Medusa. Signs: : Journal of Women in Culture and Society, 1(4), 875-893.

Fuss, D. (1989). Essentially speaking: feminism, nature and difference. New York: Routledge.

Grosz, E. (1994). Volatile bodies: toward a corporeal feminism. Bloomington: Indiana University Press.

Hammond, H. (1977). Feminist abstract art: a political viewpoint. Heresies, 1(1), 66-70.

Jones, A. (2006). Self/image: technology, representation and the contemporary subject. London: Routledge.

Jones, A. (2008). 1970/2007: the return of feminist art. X.TRA Contemporary Art Quarterly, 10(4).

Jones, A. (Ed.). (2003). The feminism and visual culture reader. London Routledge.

Lennon, K. (2010). Feminist perspectives on the body. In E. N. Zalta (Ed.), The Stanford Encyclopedia of Philosophy (Fall 2010 ed.).

Marsh, A. (1993). Body and self: performance art in Australia 1969-92. Oxford: Oxford University Press. 
Millner, J. (2015). Contemporary Australian performance art: the feminist legacy. Broadsheet Contemporary Visual Art + Culture: Art | Criticism | Theory, 44(2), 7-10.

Nochlin, L. (1988). Women, art and power and other essays. Boulder: Westview Press.

Owens, C. (1994). Beyond recognition: representation, power and culture - Craig Owens (S. Bryson, B. Kruger, L. Tillman \& J. Weinstock Eds.). Berkeley: University of California Press.

Reckitt, H. (Ed.). (2012). Art and feminism. New York: Phaidon.

Reilly, M., \& Nochlin, L. (Eds.). (2007). Global feminisms: new directions in contemporary art. London: Merrell.

Robinson, H. (Ed.). (2001). Feminism - art - theory: an anthology 1968 - 2000. Malden: Blackwell Publishing.

Schor, N. (1995). Bad objects: essays popular and unpopular. Durham: Duke University Press.

Schor, N., \& Weed, E. (Eds.). (1994). The essential difference: Brown University.

White, A. (2011). Revisiting the dawn of postmodernism - and feminist art - at the Nasher. Indy Week, 2013(12/10/2011), exhibition review. http://www.indyweek.com/indyweek/revisiting-the-dawn-of-postmodernismandfeminist-artat-the-nasher/Content?oid=2680631

Wykes, M., \& Gunter, B. (2005). The media and body image: if looks could kill. London: Sage Publications.

Zeglin Brand, P., \& Korsmeyer, C. (Eds.). (1995). Feminism and tradition in aesthetics. Pennsylvania: The Pennsylvania State University press. 